\title{
Kejayaan Lada Hingga Praktek Perburuhan di Lampung Abad ke XVIII Hingga Abad XX
}

\author{
Karsiwan \\ Tadris IPS IAIN Metro \\ Jl. Ki Hajar Dewantara No.15A, Kota Metro, Lampung \\ karsiwan@metrouniv.ac.id
}

\begin{abstract}
Abstrak
Abstrak: Kejayaan Lada Hingga Praktek Perburuhan di Lampung Abad ke XVIII Hingga Abad XX. Tujuan dari tulisan ini adalah untuk mengetahui kejayan lada Lampung dan praktek perburuhan yang terjadi di dalamnya, dari abad XVIII-XX. Metode penelitian yang digunakan adalah metode penelitian sejarah, dengan empat unsur utama yaitu: heuristik, kritik sumber, interpretasi, dan historiografi. Penelitian ini termasuk penelitian kualitatif karena menggunakan sumber dari data hasil tinjauan pustaka dan dokumentasi. Berdasarkan hasil pengumpulan data, kejayaan lada Lampung dan praktek perburuhan yang terjadi di dalamnya dari abad XVI-XX merupakan dua hal yang saling mendukung. Lada di Lampung dikenal dengan sebutan Lampung Black Papper karena kualitas dan ketenarannya, di masa Kesultanan Banten budidaya lada berkembang pesat dengan banyaknya perintah penanaman lada oleh Sultan melalui piagam yang dikirimkan ke pemimpin adat (Punyimbang). Pada awalnya praktek perburuhan di Lampung dilakukan secara sukarela, pada masa awal budidaya lada, dan berubah sejak Lampung berada di bawah Kesultanan Banten dengan perintah penanaman lada yang semakin besar, setelah kedatangan kolonialisme Belanda. Perburuhan masa itu terbagi menjadi tiga kelas yakni, 1) Buruh Lepas, 2) Buruh Bebas, 3) Buruh Kontrak.
\end{abstract}

Kata Kunci: Lada, Buruh, Kolonialisme Belanda, Banten, Lampung

Abstrack: Triumph of Pepper to Labor Practices in Lampung XVIII Century to XX Century. The purpose of this study was to determine the Lampung pepper seizure and labor practices that occurred in it from the XVI-XX century. This study uses historical research that has 4 elements of heuristics, criticism, interpretation and historiography. This research included in qualitative research because it uses the source of the data results, literature study, and documentation techniques.Based on the results of data collection, the glory of Lampung pepper and labor practices that occurred in it from the XVI-XX century are two things that mutually support Pepper in Lampung known as Lampung Black Papper because of its quality and fame, in the days of the Banten Sultanate, pepper cultivation grew rapidly with many orders the planting of pepper by the Sultan through a charter sent to the adat leader (Punyimbang). At first the practice of labor in Lampung was carried out voluntarily in the early days of pepper cultivation, and changed since Lampung was under the Sultanate of Banten with the instruction to plant pepper, and it became more massive after the arrival of Dutch colonialism. Labor is divided into 3 namely, 1) Freelancers, 2) Free Laborers, 3) Contracted Workers.

Keywords: Pepper, Labor, Dutch Colonialism, Banten, Lampung 


\section{Pendahuluan}

Kepulauan Nusantara sudah dikenal sebagai wilayah penghasil komoditas rempahrempah unggulan, seperti: lada, pala, kopi, dan cengkeh. Hal ini mendorong bangsa-bangsa Eropa berlomba-lomba untuk mengadakan hubungan perdagangan dengan penduduk pribumi seperti bangsa Portugis, Cina, Arab, hingga Belanda. Malaka merupakan titik pertemuan semua jalur rempah-rempah yang penting sepanjang abad ke XVIII hingga permulaan awal abad ke $X X$, dari dunia timur dan akan berlayar ke barat. ${ }^{1}$

Lampung merupakan daerah di ujung selatan Pulau Sumatera. Hal ini menjadikannya penghubung antara Pulau Jawa dan Pulau Sumatera. Wilayah ini sejak dahulu terkenal dengan komoditas rempah jenis lada, sehingga membuat Lampung menjadi wilayah yang strategis sebagai tempat yang mudah untuk berhubungan dengan daerah lainnya di Nusantara. Hal ini justru menarik para penguasa untuk datang serta menguasai wilayah ini. ${ }^{2}$ Dalam catatannya menyebutkan ada beberapa wilayah Lampung yang menjalin hubungan dengan Jawa dan Sunda yaitu negeri Sekampung dan negeri Tulangbawang. Dilihat dari letak geografis wilayah Lampung, memiliki lokasi yang strategis berada di tepi Selat Sunda.

Rempah yang dijuluki King of Spices ini menjadi salah satu komoditas yang diburu oleh penjelajah Eropa. Bahkan ${ }^{3}$ mengungkapkan bahwa Pesta ramalan di Woodstock di kerajaan Skotlandia menggunakan banyak sekali rempahrempah seperti (lada, kayu manis, cengkih, pala, dan jahe) dalam hidangan dan jamuan pesta yang diselenggarakan tahun 1256. Bahkan setiap jamuan pesta yang dilakukan tanpa melibatkan rempah akan membuat tuan rumah merasa terhina dan gagal dalam memuliakan tamunya. Seperti yang kita ketahui, perburuan rempahrempah oleh bangsa Eropa tersebut lantas berujung pada kolonialisme, perburuhan, dan monopoli perdagangan rempah.

Lada Lampung dikenal dengan istilah Lampung black papper sudah menjadi primadona komoditas rempah-rempah dan diekspor ke berbagai penjuru dunia sejak abad ke-XVI. Pada masa kejayaannya, lada merupakan bahan rempah yang sangat diminati oleh banyak orang yang berasal dari bangsa Arab, Timur Asing, hingga Eropa sebagai penambah citarasa masakan, sehingga banyak saudagar asing berdatangan ke Nusantara, khususnya wilayah penghasil rempah. Lada Lampung banyak dijual melalui Pelabuhan Banten, mengingat Lampung pernah dikuasi oleh Kesultanan Banten. Selain di Lampung, menurut Soedewo (2007: 20), ${ }^{4}$ Lada banyak diproduksi di perkebunan di Pulau Sumatera dan masuk ke dalam wilayah kekuasaan Kesultanan Banten seperti Lampung, Palembang, dan Bengkulu.

Pada tahun 1682 terjadi pergolakan di Banten, yaitu perselisihan antara Sultan Ageng Tirtayasa Penguasa Kesultanan Banten, dengan putra mahkota Sultan Haji. Perselisihan ini lambat laun meningkat menjadiperang, perebutantahtaKesultanan Banten. Sultan Haji terdesak dan minta bantuan dari VOC dengan janji berupa imbalan penyerahan beberapa daerah yang dikuasai Tirtayasa berikut negeri-negeri lada yang menjadi pasar Banten termasuk Lampung. Permintaan ini termuat dalam suratnya tertanggal 12 Maret 1682 yang dikirim kepada Mayor Issac de Saint Martin, pemimpinan rombongan kapal VOC dari Betawi yang sedang berlabuh di Banten. ${ }^{5}$

Dengan adanya perjanjian yang sangat menguntungkan ini, maka pada tanggal17 April 1682 tentara VOC mendarat di Banten, menyerang Pasukan Tirtayasa dan berhasil mengalahkannya. Sultan Haji berkuasa di Banten, kemudian diangkat dan diakui sebagai Sultan Banten yang sah oleh VOC. Sebagai imbalan dan hutang budinya kepada VOC, Sultan pada tanggal 22 Agustus 1682 melakukan perjanjian kerjasama dengan menandatangani surat di mana VOC mendapatkan hak monopoli perdagangan lada. Dan sejak itu, Belanda secara yuridis mempunyai perdagangan lada di Lampung. Kejayaan lada Lampung selain mampu menjadikan Lampung 
sebagai sentra ekonomi pada masanya, di sisi yang lain juga membuat kebutuhan tenaga kerja menjadi meningkat.

Praktek perburuhan di Lampung sudah terjadi sejak tanaman lada memiliki nilai jual yang tinggi, serta awal kemunculannya merupakan kegiatan yang dilakukan secara sukarela antara pemilik lada dengan para pekerja dari Jawa. Keadaan ini terus berlangsung hingga masa di mana wilayah Lampung berada di bawah kekuasaan kesultanan Banten. Awalnya tenaga kerja dari Jawa khususnya Banten berdatangan secara sukarela yaitu saat di mana musim tanam padi telah berlalu, sambil menunggu masa panen tiba dan untuk tetap menjaga keadaan ekonomi tetap berjalan, mereka datang ke Lampung sebagai buruh petik lada.

Kondisi berbeda saat Lampung berada di bawah kekuasaan Belanda. Praktek perburuhan di wilayah Lampung mulai diberlakukan melalui serangkaian kebijakan dan peraturan. Keadaan ini tentunya tidak dapat dilepaskan dari kebijakan politik pemerintah kolonial Belanda. Kebijakan politik mulai dari kebijakan pintu terbuka hingga kebijakan etisnya. Wilayah Lampung dengan hasil perkebunan seperti lada, damar, kapuk, dan gambir, kemudian masyarakatnya mulai membudidayakan tanaman kopi, sejak akhir pertengahan abad ke-19.

Sama halnya dengan pola perkebunan pada umumnya, Way Lima merupakan daerah frontier yang secara sosial, ekologis, dan historis terpisah dari pusat yang saat itu berada di Teluk Betung (Tembok-tembok pemisah dari daerah di sekitar perkebunan), menurut Ann Laura Stoler, hal itu sebagai cara untuk mengontrol buruh secara total. Hal ini tergambarkan di Deli yang awalnya daerah frontier kemudian menjadi sebuah lokalitas perkebunan yang di dalamnya juga terdapat suatu sistem. ${ }^{6}$

Kebijakan etis berangkat dari sebuah pernyataan Ratu Wilhelmina dalam pidatonya menyampaikan, bahwa pada tahun 1901 menyatakan bahwa, pemerintah kolonial akan melakukan perbaikan nasib penduduk pribumi Indonesia, melalui tiga kebijakan politiknya, yaitu: pengembangan pendidikan (edukasi), pembangunan pertanian (irigasi), dan pemindahan penduduk (emigrasi). Kebijakan ini kemudian dikenal sebagai politik etis (balas budi). Untuk menindaklanjuti pidato itu dan mencermati isu tentang keadaan ekonomi penduduk sebagai dampak dari politik tanam paksa dan liberal, pada tahun itu juga Ratu Belanda menganjurkan supaya diadakan kajian dan penelitian di bidang kependudukan, ekonomi, pajak, dan kerja wajib di wilayah Jawa dan Madura.

Implementasi kebijakan politik etis pemerintah kolonial Belanda yaitu dilaksanakannya program kolonisasi pertama dengan penempatan di Desa Bagelen, Gedongtataan, Lampung. Adanya politik etis bermula dari timbulnya berbagai kritik, terutama golongan liberal di negeri Belanda terhadap kebijakan pemerintah terkait kondisi bangsa jajahan di Hindia Belanda. Kritikan itu, semula disampaikan kaum oposisi tahun 1860. Kemudian kritik ini menjadi luas lagi sebab, selain dari oposisi, juga datang dari beberapa tokoh yang memang bersimpati terhadap rakyat dan bangsa Indonesia.

Proses pemindahan penduduk dari Pulau Jawa merupakan implementasi kebijakan politik etis. Pemindahan ke luar pulau, pada kenyataannya justru disinyalir menjadi sarana mendatangkan pekerja untuk dijadikan buruh yang akan dipekerjakan di perkebunan atau pertambangan swasta Belanda yang sudah ada sebelumnya. Kondisi terlihat pada penempatan para kolonis di sekitar perkebunan swasta milik Belanda, dan ditempatkan di antara lokasi penduduk asli Lampung (seperti Bagelen yang terletak di antara Teluk Betung dan Kota Agung. Kolonisasi Trimurdjo terletak di antara Tegineneng dan Sukadana). Para buruh kontrak yang didatangkan dari Pulau Jawa, dipindahkan ke perkebunaan karet di Way Lima, Gedong Tataan Provinsi Lampung hari ini.

Hal yang sama terjadi pula pada 
penerapan bidang irigasi sebagai bagian kebijakan etis pemerintah kolonial Belanda yang ada. Banyak jaringan irigasi yang dibangun di Lampung seperti di Pringsewu dan irigasi Argoguruh (Pesawaran). Sesungguhnya irigasi bukan untuk mengairi sawah milik petani, akan tetapi lebih banyak digunakan untuk mengairi perkebunan karet milik swasta.

Untuk itu peneliti perlu mengkaji bagaimana kondisi kejayaan Lada Lampung dan praktek perburuhan di Lampung pada masa abad ke-18 hingga awal abad ke-20. Hal ini dilakukan untuk mengkaji perubahan dan perkembangan sosial ekonomi di lampung dalam kaitannya antara kejayaan lada dan praktek perburuhan yang terjadi dalam perkebunan dan perdagangan lada dalam kaitannya dengan kebijakan pemerintah kolonial Belanda di Lampung.

Lada merupakan jenis tumbuhan merambat yang tumbuh dan berkembang melalui bantuan tanaman penopang. Lada tumbuh maksimal pada daerah yang beriklim tropis, di mana lada banyak digunakan sebagai penambah citarasa dan bumbu masakan. Lada memiliki rasa dan aroma yang sangat khas, menjadikan tanaman ini sebagai bahan pelangkap dari resep masakan andalan. ${ }^{7}$

Konsep pemerintah kolonial Belanda menurut Karsiwan (2013: 12) ${ }^{8}$ adalah suatu pemerintahan yang didirikan di atas kekuasaan negara lain baik melalui perjanjian, dan penaklukan, serta tak jarang menggunakan cara peperangan. Dengan tujuan untuk menguasai wilayah yang didudukinya, beserta segala potensi yang ada. Pemerintah kolonial dalam hal ini merupakan suatu perpanjangan tangan negara induk untuk mengatur, mengontrol, dan menguasai seluruh sumber daya negara jajahan.

Menurut UU RI Nomor 13 Tahun 2013 tentang ketenagakerjaan, yang dimaksud pekerja/buruh adalah setiap orang/individu yang bekerja dengan mendapatkan upah atau imbalan dalam bentuk lain (Pasal 1 ayat 3). Buruh pada dasarnya adalah manusia yang menggunakan tenaga dan kemampuannya untuk mendapatkan balasan berupa penghasilan baik berupa uang ataupun bentuk lainnya kepada pemberi kerja atau pengusaha.

Adapun tahapan dalam penelitian ini meliputi heuristik, verifikasi data (kritik intern dan ekstern), interpretasi, dan historiografi. ${ }^{9}$ Pada tahap heuristik atau pengumpulan data, peneliti terlebih dahulu menentukan topik yang akan dibahas yakni kejayaan lada Lampung, hingga praktek perburuhan yang terjadi di dalamnya sejak abad ke-18 hingga awal abad ke-20. Tahap selanjutnya yaitu verifikasi data atau kritik intern dan ekstern, untuk melihat keaslian dan reabilitas sumber data sejarah yang didapatkan. Kritik ekstern yang dilakukan oleh peneliti dilakukan dengan melihat keterkaitan antara kejayaan lada Lampung dengan berkembangnya praktek perburuhan di Lampung sejak abad ke-18 hingga awal abad ke-20. Tahap selanjutnya interpretasi, dilakukan berdasarkan fakta dan juga data yang diperoleh sehingga tidak hanya imajinasi semata, untuk itu peneliti mencantumkansumberdatayangdigunakan. Pada tahap interpretasi, sumber-sumber primer yang telah didapatkan dibandingkan dengan sumber-sumber lain, baik sekunder ataupun tersier. Hal ini dilakukan agar tidak ada kesalahan pemaknaan. Pada tahap ini, peneliti berupaya untuk mengkaitkan antara faktayangsatudenganfaktalainnya,sehingga diperoleh sebuah gambaran peristiwa secara utuh dan kronologi serta saling berkaitan antara lada dan perburuhan di Lampung. Tahap terakhir historiografi yaitu penulisan sejarah. Penulisan sejarah disusun secara kronologis dan memperhatikan aspek kausalitas. Pembahasan mengenai kejayaan lada Lampung hingga praktek perburuhan yang terjadi di dalamnya sejak abad ke-18 hingga awal abad ke-20.

\section{Pembahasan}

\section{Lada Lampung}

Umumnya Masyarakat Sumatera, membagi lada menjadi tiga jenis dengan nama yang berbeda-beda pada tiap 
wilayah. Di Laya, Kerajaan Rejang mereka menyebutnya dengan nama Lado Kawur, Lado Manna, dan Lado Jambi, di mana namanama lada tersebut diambil dari tempat di mana lada pertama kali dibawa. ${ }^{10}$ Lada (merica) di tanah Lampung terbagi menjadi 2 jenis lada, yaitu lada Cenging dan lada Jambi. ${ }^{11}$ Kedua jenis lada ini memiliki biji yang lebih besar,biasanya deposan diperoleh dengan menempatkan cabang muda sedemikian rupa, sehingga bagian atas berada di luar, dan setelah beberapa minggu, cabang itu berakar dan potongannya dipotong dari batangnya.

Lada Lampung dikenal dengan istilah lada kawur, jenis lada Lampung merupakan yang terkuat daripada jenis lada manna dan lada Jambi dengan ukuran buah dan daun yang paling besar. Lada Lampung memiliki fase perkembangan dan pertumbuhan lada lebih lambat daripada kedua jenis lada yang lain. Secara umum, wilayah Lampung memiliki beberapa jenis lada, yaitu lada hitam di sebagian besar wilayah Lampung dan jenis lada putih yang dihasilkan di daerah Tulang Bawang pada masanya.

Budidaya lada di wilayah Lampung tersebar di berbagai lokasi, mulai dari kawasan timur, utara, barat, hingga selatan seperti daerah Sekampung dan Sukadana di Lampung Timur, Katimbang di Kalianda Lampung Selatan, Tulang Bawang di Utara, Semangka, Tanggamus dan Teluk Betung. Luas lahan budidaya lada di Lampung merujuk pada artikel yang telah dibukukan dengan judul De Pepercultuur in de Buitenbezittingen, tentang luas lahan dan wilayah yang digunakan dalam budidaya lada di Lampung sampai tahun 1912 sebagaimana pada tabel 1 berikut.

Tabel 1: Luas Lahan Budidaya Lampung tahun 1912

\begin{tabular}{|c|c|c|c|}
\hline \multirow[t]{2}{*}{ No } & \multirow[t]{2}{*}{ Nama Daerah } & \multicolumn{2}{|c|}{$\begin{array}{l}\text { Luas } \\
\text { Garapan }\end{array}$} \\
\hline & & Bau & $\begin{array}{l}\text { Dalam } \\
\text { hektar }\end{array}$ \\
\hline 1 & Sekampung & \pm 2400 & 1680 \\
\hline 2 & Seputih & \pm 2300 & 1610 \\
\hline
\end{tabular}

$\begin{array}{llll}\mathbf{3} & \text { Semangka } & \pm 940 & 658 \\ \mathbf{4} & \text { Teluk Betung } & \pm 900 & 630 \\ \mathbf{5} & \text { Tulang } & \pm 800 & 560 \\ & \text { Bawang } & & \end{array}$

$\begin{array}{lrrr}6 & \text { Katimbang } & \pm 50 & 35 \\ & \text { Total } & \pm 7390 & 5173\end{array}$

Sumber: Karsiwan, Kejayaan Lada Hingga Praktek Perburuhan di Lampung Abad XVI-XX, hal. 112

Dari luas lahan berdasarkan tabel di atas, baru sekitar 1.470 bau dari 7.390 bau luas lahan yang tersedia, yang telah ditanam dengan bibit lada yang belum berbuah, sehingga terdapat sekitar 5.920 tanaman lada yang dapat dikategorikan sebagai tanaman produktif. Ketika proses penanaman lada pada cabang-cabang muda dengan luas 1.470 yang disebutkan di atas, kebun-kebun tua atau kebun-kebun lada yang menghasilkan tanaman yang kemudian ditinggalkan.

Dengan luas tanah dan jumlah budidaya lada yang terus meningkat di Lampung, maka dapat diasumsikan, dengan perkiraan usia produktif tanaman lada dapat mencapai hingga 14 tahun. Hasil budidaya lada di wilayah Lampung berdasarkan tabel di atas menunjukkan bahwa puncak hasil panen lada terjadi pada tahun ke delapan dan kesembilan dari masa awal tanam lada. Hasil lada pada tahun tersebut mencapai 25 pikol/ bau tanaman lada masyarakat Lampung. Siklus tanaman lada kemudian berangsur turun ke kondisi semula pada tahun ke empat belas dan seterusnya. Lada hitam diproduksi dengan cara apabila setangkai terdapat satu atau dua yang merah maka baru dapat dipanen. Musim panen dimulai pada bulan Juli atau Agustus, lamanya sampai 3 bulan. Akan tetapi pada bulan April biasanya mulai masuk musim kemarau dan harus disiram.

Proses memanen lada menggunakan sebuah tangga seperti huruf A, dengan 
cara setiap tandan buah lada dipetik setangkai demi setangkai. Hasil panen lada, berapapun jumlah hasil panen dalam satu hari dibawa pulang ke kampung. Setiap hari dijemur didepan rumah menggunakan alas atau nyiru. Jika sudah kering kulitnya akan mengelupas kemudian tangkainya dipotongdandibuang, setelahitukemudian dimasukkan kedalam karung dan disimpan dalam rumah-rumah penduduk yang berbentuk rumah panggung.

Di Lampung proses pembersihan lada, umumnya dengan cara disimpan pada sebuah kandang/gudang penyimpanan, yaitu yang dibuat pada sebidang tanah di pekarangan rumah yang dilapisi tikar sebagai lantai, dan apabila telah layak untuk dijual, lada akan disimpan pada sebuah babalang atau kecundang yang terbuat dari anyaman bambu atau rotan dan bisa diangkat atau dijinjing. ${ }^{12}$

Untuk membedakan kualitas setiap lada, terdapat cara tradisional yang digunakan yakni dengan cara menggenggam lada, apabila lada setelah dikeringkan masih melekat dalam genggaman, maka lada masih memerlukan penjemuran untuk menurunkan kadar air didalamnya. Sebaliknya apabila lada lepas dari genggaman ini menandakan bahwa sebuah lada sudah memiliki kualitas yang baik dan siap untuk dijual.

Selain lada hitam di Lampung juga terdapat hasil produksi lada putih. Sama dengan lada hitam hanya pengolahannya yang berbeda. Pertama, lada yang akan dibuat putih itu harus dipilih yang berwarna merah semua sesudah dipanen, selanjutnya lada dimasukkan dalam karung, kemudian ditimbun di dalam tanah selama kurang lebih dua minggu, lalu diambil dan dimasukkan ke dalam air yang mengalir. Hal ini dilakukan dengan tujuan supaya, bijinya terlepas dari tangkai, sesudah itu digilas di dalam ayakan besar, sampai kulitnya pun terlepas dari biji. Tahap selanjutnya lada dikeringkan di bawah sinar matahari selama kurang lebih tiga hingga empat hari. Pada umumnya lada putih banyak dihasilkan di daerah
Tulang Bawang, Lampung, meskipun dengan kualitas yang berbeda-beda dari lada putih yang dihasilkan dari daerah lain seperti kepualauan Bangka.

\section{Kejayaan Lada Lampung}

Sistem penanaman lada di Lampung sebagian besar masih dilakukan secara kultur ekstensif pada masanya. Lahan yang akan dijadikan budidaya lada atau lahan garapan merupakan hasil pemilihan atas hutan sekunder dan atau bekas hutan primer yang telah dibuka dan diolah menjadi perladangan dan layak untuk penanaman. Tanaman lada umumnya dapat tumbuh secara optimal pada tanah yang tidak terlalu kering dengan musim hujan yang lebih panjang daripada musim kemarau, meskipun demikian lada amat peka terhadap genangan air dalam tanah.

Burger menggambarkan betapa elite birokrat dan saudagar menjadi kaya raya, hal itu terlihat mereka memiliki rumah mewah, tanah, kapal, dan lainnya. ${ }^{13} \mathrm{Hal}$ ini jauh berbeda dengan kehidupan para buruh, yang hidup jauh dari kata cukup. Pada masa itu stratifikasi sosial semakin menunjukkanjurang pemisah antara si kaya dan si miskin. Perbedaan dan tingkat sosial sangat menonjol, bagaimana elit birokrat dan saudagar perdagangan menjadi kaya raya pada satu sisi, dan kehidupan para buruh pada kondisi lainnya. Bahkan dalam perkembangannya, kehidupan para buruh lambat laun menjadi semakin dikendalikan dan dalam genggaman para pemilik perkebunan, dan ia (para buruh) bisa dibilang tidak memiliki kebebasan dalam menetukan hasil dari perkebunan lada yang ia tanam.

Wilayah Lampung mampu menghasilkan lebih banyak lada daripada hasil budidaya lada di wilayah Banten sendiri. De Rovere van Breugell seorang pengusaha Belanda dengan pengalamannya dalam melakukan bisnis dan perdagangan dengan Kesultanan Banten, melaporkan bahwa, hampirseluruh lada Lampung mampu memasok seluruh Perusahaan dagang VOC dengan jumlah rata-rata 9.000 bahar selama satu abad. Bahkan pasokan lada ini sudah terjadi sejak 
tahun-tahun sebelumnya, dengan jumlah mencapai 19.000, 13.000, 11.000 bahar. $^{14}$

Dari angka-angka di atas jelas terlihat betapa hasil panen lada Lampung pada abad 17 dan 18 sangat besar. Pada kenyataannya, produksi lada tidak pernah terjadi seperti sekarang ini. Broersma dalam laporannya memprediksi jumlah produksi lada mencapai lebih dari 50.000 picul per tahun, meskipun ini hanya merupakan data perkiraan. Hal ini tentunya memberikan sebuah gambaran awal yang didukung dengan fakta bahwa banyak terdapat bankbank yang didirikan pemerintah Kolonial Belanda dalam mendukung budidaya lada di Lampung. Bank ini memberikan pinjaman modal dengan cara menyalurkan kredit dan bantuan ekonomi kepada petani lada Lampung.

Tabel 2: Wilayah dan Sebaran Hasil Lada di Lampung Tahun 1780-1786

\begin{tabular}{lcccc}
\hline \multicolumn{1}{c}{ Wilayah } & \multicolumn{4}{c}{ Tahun } \\
\cline { 2 - 5 } & 1780 & 1781 & 1782 & 1786 \\
Seputih & 1.130 & 498 & 581 & 293 \\
Telok & 1.165 & 783 & 603 & 344 \\
\hline Kalianda & 2.900 & 2.551 & 1.473 & 1.518 \\
\hline
\end{tabular}

\begin{tabular}{lcccc}
\hline Sekampung & 639 & 789 & 307 & 210 \\
\hline Semangka & 800 & 1.239 & 1.088 & 175 \\
Pamet & 705 & 893 & 415 & 637 \\
$\begin{array}{l}\text { Tulang } \\
\text { Bawang }\end{array}$ & 100 & 37 & 20 & 25 \\
Nibung & 295 & 235 & 182 & 236 \\
\hline Total & 7.734 & 7.024 & 4.669 & 3.438 \\
\hline
\end{tabular}

Sumber: Jurnal, untuk Hindia Belanda Tahun 1862 bagian II halaman 141 e.v. dalam Broersma, Lampongsche Districten ha1. 169

Berdasarkan tabel 2 diatas, dapat disimpulkan bahwa dari rata-rata 17.142 picol per tahun, yang hasilnya ternyata lebih rendah dari dua puluh tahun sebelumnya. Saat komoditas perdagangan lada mengalami penurunan, maka proses penanaman lada juga mengalami penurunan. Pada 1798-1802, rata-rata hasil lada hanya mencapai 6.514 picol per tahun dan pada 1810 rempah-rempah jenis lada hampir benar-benar menghilang dari situasi di pasaran. Pernah suata ketika untuk memperkenalkanlada kembali, maka petani lada dari Lampung diperintahkan untuk melakukan pengiriman lada ke Pemerintah. Ternyata hal itu tidak dapat dipenuhi oleh penduduk lampung ketika itu, dikarenakan terjadi lonjakan harga lada di pasaran yang sudah terlalu tinggi, dan telah naik terlalu banyak.

Penyelidikan menyeluruh pada tahun 1841 menunjukkan bahwa Pemerintah harus membayar $f 12$.- dalam tembaga atau $f$ 10.- dalam perak per picul lada, sehingga setelah peningkatan dengan biaya yang diperlukan itu tidak dapat memperoleh manfaat apapun. Petani lada Lampung mendapat hasil pembayaran yang lebih tinggi dari harga penawaran biasanya dan harga pasar naik menjadi $f 17$ hingga $f 18$.

Angka produksi hasil budidaya lada di Lampung juga sangat fluktuatif, namun pada dasawarsa pertama abad XX, panen lada Lampung tahun 1911 diperkirakan mencapai 180.000 picol, tetapi dengan mempertimbangkan kondisi cuaca yang tidak terlau baik bahkan cenderung buruk maka produksi lada diperkirakan hanya 130.000 picol. Data-data menunjukkan bahwa semua transaksi jual beli lada, tidak mungkin untuk memperkirakan produksi untuk dua tahun ke depan, terutama mengingat mahalnya harga lada saat itu. Fluktuasi harga jual lada diakhir abad ke-19 mengakibatkan pekebun lada lebih memperhatikan kebun yang berproduksi rendah dan lebih memperhatikan pemeliharaan, sehingga dengan itu dapat meminimal resiko dan tidak berpengaruh pada angka produksi.

\section{Perburuhan}

Para pemilik kebun menanam lada mulai dalam skala kecil hinga besar tergantung pada kemampuan petani lada. Pada skala kecil, proses penanaman lada umumnya dilakukan oleh petani dengan hanya mengandalkan tenaga kerja dari 
keluarganya dengan jumlah yang bisa ditanam. Biasanya berjumlah 333 hingga 1000 sulur, dan kemudian dibantu oleh keluarganyadalampengolahan, perawatan, hingga proses panen.

Buruh pribumi hanya dapat dipekerjakan dan disewa oleh pedagang dari pemiliknya, setelah dilakukan peminjaman jasa buruh dari majikannya. Para majikan biasanya selalu meminta bayaran tinggi untuk jasa para buruh miliknya. Karena sudah menjadi kebiasaan yang umum dilakukan, di mana setiap majikan menyewakan budak-budak mereka. Para pedagang dari Eropa membayar budakbudak itu dengan sejumlah uang yang akan diberikan kepada tuannya, kemudian mereka dapat menggunakan tenaga budak itu untuk pekerjaan apapun yang diinginkan. ${ }^{15}$

Pada masa ini, buruh adalah hak milik majikan suatu ikatan yang umumnya didasarkan atas utang piutang, yang ketaatannya bersifat kuat, akrab dan mengikat, namun juga sekaligus dapat berpindah dan atau diperjualbelikan. Kepemilikan diartikan sebagai segala sesuatu yang menyangkut kehidupan para buruh baik persoalan ekonomi, gaji hingga hidup dan matinya seorang buruh. Keadaan ini tak ubahnya perbudakan manusia, dengan segala dalih dan pijaknnya, setiap buruh seperti budak-budak milik tuannya.

Terdapat pengecualian tertentu, pengolahan lada setelah lahan siap ditanam menggunakan para buruh yang di sewa. Buruh sewaan ini digunakan tenaganya ketika proses membangun kebun lada, sejak dimulainya pengolahan lahan, pembersihan lahan, penanaman bibit, pemasangan tegakan/tanaman penopang. Buruh tanam lada selalu didatangkan dari Banten pada masanya. Selalu ada banyak pertimbangan mengapa para pekerja asal Banten yang digunakan, selain tentunya ketersediaan buruh kerja dalam jumlah yang memadai, faktor kedekatan geografis antara Lampung-Banten pun nampaknya cukup mampu untuk dikedepankan dalam mendukung gagasan ini.
Proses budidaya lada sejak awal dilakukan mulai dari penanaman, pemeliharaan dan panen dalam budidaya skala kecil dilakukan oleh setiap kepala keluarga beserta keluarganya. Jarang dijumpai penanaman dalam jumlah besar tanpa dilakukan persiapan dengan penyediaan tenaga kerja yang cukup, sehingga diperlukan modal tambahan untuk pengerjaan budidaya lada ini untuk mendatangkan para pekerja atau buruh. Besaran upah yang harus disiapkan untuk budidaya lada beserta tenaga kerja ialah:

\begin{tabular}{|c|c|c|}
\hline No. & Jenis Pengeluaran & Biaya \\
\hline 1. & Upah menanam potongan & $f 13,50$ \\
\hline 2. & Upah pengemasan stek lada & $f 13,50$ \\
\hline 3. & $\begin{array}{l}\text { Upah pemeliharaan selama } \\
\text { empat tahun pertama ( } 160 \\
\text { hari pada } f 0,75 \text { per hari) }\end{array}$ & $f 120$ \\
\hline 4. & $\begin{array}{l}\text { Upah pemeliharaan selama } \\
\text { empat tahun kedua ( } 120 \text { hari } \\
\text { pada } f 0,75 \text { per hari) }\end{array}$ & $f 90$ \\
\hline 5. & $\begin{array}{l}\text { Upah pemeliharaan lainnya } \\
\text { (100 hari pada } f \quad 0,75 \text { per } \\
\text { hari) }\end{array}$ & f 75.- \\
\hline 6. & $\begin{array}{l}\text { Upah pemangkasan dadap, } \\
6 \text { kali selama keberadaan }\end{array}$ & $f 81$. \\
\hline
\end{tabular}

Sumber: De Pepercultuur in de Buitenbezzittingan, hal. 37: Karsiwan (2019:126) ${ }^{2}$

Perjanjian kerja tertentu tidak dapat kita bahas dan bicarakan mengingat sumber data yang amat terbatas terkait perjanjian kerja antara pemilik kebun dengan para buruh, terlebih fakta masyarakat kita bahwa umumnya perjanjian kerja dilakukan secara lisan. Upah harian pekerja umumnya terbagi atas dua, yang pertama berjumlah antara $f \quad 0,60$ hingga $f$ 0,75 tanpa makan dan minum ataupun tunjangan lainnya, sedangkan yang kedua antara $f 0,33$ hingga $f 0,50$ dengan biayanya tambahan seperti makanan, minuman dan kadang-kadang juga rokok pekerja, dan ini juga belum termasuk akomodasi bekerja di kebun petani Lampung di tempat terpencil.

Tambahan lain apabila pekerja ikut 
membuat gudang hasil panen, dan memilih untuk ikut berjaga dan tinggal didalamnya. Bagi pedagang awal Eropa, dalam membantu urusan tata niaga di pelabuhan mereka berusaha untuk menyewa para buruh di pelabuhan dengan upah yang dirasa begitu besar. Di wilayah Kesultanan Banten, termasuk daerah Lampung seorang buruh dibayar untuk bekerja dengan upah 3 gantang per hari.

Budidaya lada semakin gencar dilakukan saat Sultan Abdul Muhasin pada tahun1694, bahwasultanmewajibkansetiap penduduk Lampung untuk menanam lada dalam jumlah yang cukup banyak mulai dari 400, 500 hingga 600 batang lada/ kepala. Keadaan ini tergambar dalam undang-undang yang diterbitkan Sultan dalam prasasti untuk daerah Putih (kuat dugaan yang dimaksud daerah ini adalah daerah Putih Doh), yang berbunyi:

"merica (lada) dapat dijadikan sebagai alat tukar, dan dalam perkara hutang piutang, mereka dikenai keharusan menanam lada sebanyak 500 pohon untuk setiap orang dan hasilnya dibawa ke Banten dengan disertai surat pemberitahuan dan cap jual beli"16

\section{Jenis Perburuhan}

Praktik perburuhan selama masa pemerintahan kolonial Belanda di Lampung, dapat diklasifikasikan menjadi beberapa kelompok. Menurut Hoedt (1930: 78), ${ }^{2}$ buruh/tenaga kerja dapat dibedakan menjadi 3 kelompok secara garis besar, yaitu: 1) Buruh Lepas, 2) Buruh Bebas, dan 3) Buruh Kontrak

\section{Buruh Lepas}

Buruh lepas ialah kelompok pekerja yang berasal dari wilayah Lampung, meskipun dalam jumlah yang sangat terbatas, maupun pendatang yang memang berniat untuk bekerja. Buruh jenis ini berafiliasi dengan perusahaan untuk layanan tertentu, tetapi tidak berkewajiban menyediakan kapasitas kerja bagi pemberi kerja di luar layanan yang disepakati tersebut. Buruh jenis ini banyak digunakan untuk jenis pekerjaan tertentu seperti pembukaan lahan, penebangan hutan, pembangunan rumah, dan pembuatan jalan.

Para buruh yang datang ke Lampung umumnya bekerja di sela-sela waktu penanaman padi, yakni jeda antara setelah penanaman padi dan menjelang panen kisarannya selama 3 bulan dengan tujuan untukmendapatkanpenghasilantambahan, sambil menunggu waktu panen. Jumlah buruh lepas yang bekerja di perusahaanperusahaan perkebunan hingga bulan April 1927, tercatat mencapai sekitar 1.250 orang, dengan perkiraan mencapai $8 \%$ dari total jumlah buruh yang dipekerjakan di banyak perusahaan perkebunan karet di wilayah Lampung.

\section{Buruh Bebas}

Buruh bebas ialah pekerja dari luar wilayah Lampung dan tempat perusahaan berada, dan sengaja datang sebagai pekerja. Buruh jenis ini terkait dengan perusahaan melalui perjanjian untuk waktu yang pasti, dan biasanya bekerja selama enam bulan atau lebih. Setiap perusahaan praktis tidak memiliki kuasa atas setiap buruh yang bekerja dengan jenis ini.

Pasar buruh bebas ini sangat "menguntungkan" bagi agen perusahaan penyedia tenaga buruh khususnya di daerah Sumatera Selatan. Hal ini tentunya didukung fakta tentang kurangnya tenaga kerja. Mereka jadi memiliki pemahaman, bahwa sampai pada batas tertentu perusahaan memiliki ketergantungan yang tinggi terhadap para buruh, karena setiap buruh memiliki kesadaran bahwa apabila mereka keluar, buruh pengganti belum tentu langsung tersedia menggantikan mereka.

Hal demikian menciptakan peluang besar bagi mereka untuk melakukan 
pemutusan kontrak kerja. keberanian buruh tentunya didukung asumsi bahwa memutus kontrak dikarenakan adanya peluang kerja yang menawarkan penghasilan yang jauh lebih baik.

\section{Buruh Kontrak}

Buruh kontrak ialah buruh yang berasaldariluarwilayahtempatperusahaan berada, dan telah menandatangani perjanjian kontrak kerja sebelum mereka bekerja. Kontrak kerja yang mengikat kaum buruh ini berdasarkan kepada aturan perburuhan atau kuli ordonansi yang berlaku. Para buruh kontrak direkrut menggunakan metode laukeh.

Metode laukeh yakni suatu cara merekrut buruh dengan memanfaatkan para buruh sebelumnya, sebagai agen pencari kerja. Buruh yang dimaksud ialah buruh yang kontraknya segera habis dan dikirim kembali pulang ke Jawa dengan cara melakukan propaganda kepada saudara, kerabat, tetangga, dan temannya untuk ikut bekerja di tanah seberang.

Setiap laukeh akan memperoleh upah atau imbalan dalam mencari buruh baru yang siap bekerja. Upah dalam melaksanakan tugasnya itu, setiap laukeh akan diberikan komisi sebesar $f$ 10 untuk masing-masing kepala. Untuk setiap buruh baru yang berhasil direkrut, sedangkan untuk setiap calon buruh akan memperoleh komisi sebesar $f 25$ masingmasing kepala. ${ }^{3}$

\section{Kesimpulan}

Budidaya lada di wilayah lampung tersebar diberbagailokasimulai darikawasan timur, utara, barat, hingga selatan daerah Lampung, seperti daerah Sekampung dan Sukadana di Lampung Timur, Katimbang di Kalianda Lampung Selatan, Tulang Bawang di Utara, Semangka, Tanggamus, dan Teluk Betung.

Wilayah Lampung mampu mengekspor lada hitam ke berbagai wilayah di
Hindia Belanda dengan total ekspor lada hitam baik ke luar ataupun di dalam negeri sebanyak $15.815 .448 \mathrm{~kg}$ atau sebanyak $77 \%$ dari seluruh total ekspor. Keberadaan lada pada masa kejayaan perdagangan rempah menyebabkan Lampung menjadi daerah perebutan antara Kesultanan Banten, Kesultanan Palembang, dan VOC.

Kontrak kerja antara pemilik kebun dengan para buruh di Lampung, umumnya dilakukan secara lisan dengan upah harian pekerja, dan biasanya terbagi atas dua tingkatan, yang pertama berjumlah antara $f \quad 0,60$ hingga $f$ 0,75 tanpa makan dan minum ataupun tunjangan lainnya, sedangkan yang kedua antara $f 0,33$ hingga $f$ 0,50 dengan biayanya tambahan seperti makanan, minuman, dan kadang-kadang juga rokok pekerja, dan ini belum termasuk akomodasi bekerja di tempat terpencil.

Penduduk lokal umumnya tidak bersedia bekerja di perkebunan, dengan pandangan bahwa bekerja diperkebunan merupakan pekerjaan kasar, sehingga kebanyakan buruh yang bekerja berasal dari Cina, kemudian digantikan buruh dari Jawa. Praktek perburuhan selama masa pemerintahan kolonial Belanda di Lampung, dapat diklasifikasikan secara garis besar menjadi beberapa buruh dengan kriteria, yaitu: 1) Buruh Lepas, 2) Buruh Bebas, dan 3) Buruh Kontrak.

\section{Daftar Referensi}

Broersma, R. De Lampongsche Districten. Batavia: De Javasche Boekhandel Landsdrukkerij, 1916.

Burger, DH dan Prayudi. Sejarah Ekonomis SosiologisIndonesia.PradnyaParamita: Djakarta, 1962

De Pepercultuur in de Buitenbezittingen. Batavia: Landsdrukkerij, 1913.

Hadikusuma, Hilman. Adat Istiadat Daerah Lampung. Depdikbud: Jakarta, 1977.

Ibrahim, Ibn Muhammad. 1688. The Ship of Sulaiman, terjemahan dari The Persian 
by J.O Kane. London. Routladge and Kegan Paul. 1972.

Jurnal, untuk Hindia Belanda Tahun 1862 bagian II halaman 141 e.v. dalam Broersma, R. 1916. De Lampongsche Districten. Batavia: De Javasche Boekhandel Landsdrukkerij.

Karsiwan. Kejayaan Lada Hingga Praktek Perburuhan di Lampung Abad XVI$X X$. Direktorat Sejarah, Kementerian Pendidikan dan Kebudayaan RI. Jakarta, 2019.

Karsiwan. Pembangunan Irigasi Way Tebu Sebagai Kebijakan Etis Pemerintah Kolonial Belanda di Pringsewu Tahun 1927. Jurnal Pendidikan dan Penelitian Sejarah PESAGI, 2013.

Koentjaraningrat. Metode Penelitian Masyarakat. Gramedia: Jakarta, 1997.

Marsden, William. Sejarah Sumatera. Yogyakarta: Indoliterasi, 2015.

Maryeini. Metode Penelitian Kebudayaan.

Bumi Aksara: Jakarta, 2005.

Miles, Mathew G. dan Michael Huberman. Analisis Data Kualiatif. Universitas Indonesia: Jakarta, 1992.

Nawawi, Hadari. Metode Penelitian Bidang Sosial. Gadjah Mada University Press: Yogyakarta, 2001.

Nurhakim, Lukman \& Moh. Ali Fadillah. Lada: Politik Ekonomi Banten di Lampung dalam Prosedings Analisis Hasil Penelitian Arkeologi III: Kajian Agrikultur Berdasarkan Data Arkeologi. Depdikbud: Jakarta, 1989

Soedewo, Ery. 2007. Lada Si Eman Panas: Dampaknya Bagi Kesultanan Aceh dan Kesultanan Banten. Jurnal Universitas Sumatera Utara. Medan.

Stoler, AnnLaura. Kapitalismedan Konfrontasi di Sabuk Perkebunan Sumatera, 18701979. Yogyakarta: KARSA, 2005.
Turner, Jack. Sejarah Rempah: Dari Erotisme Sampai Imperialisme. Jakarta: Komunitas Bambu.

Undang Undang Nomor 13 Tahun 2003 Tentang Ketanagakerjaan

Vierhout, M. Het Arbeidsvraagstuk in Verband met de Noodzakelijke Ontwikkeling der Buitengewesten. Weltevreden: Albrecht \& Co, 1921.

Yudianto. Tanaman Lada dalam Perspektif Autekologi. Bandar Lampung: Aura Publishing, 2015.

\section{Catatan Akhir}

${ }^{1}$ Turner, Sejarah Rempah: Dari

Erotisme Sampai Imperialisme,2019: 29.

2Pires, 223.

${ }^{3}$ Turner, Sejarah Rempah: Dari Erotisme Sampai Imperialisme, 51.

${ }^{4}$ Soedewo,Lada Si Eman Panas:

Dampaknya Bagi Kesultanan Aceh dan Kesultanan Banten, 20.

${ }^{5}$ Bukri, Sejarah Daerah Lampung, 121.

${ }^{6}$ Ann Laura Stoler, Kapitalisme dan Konfrontasi di Sabuk Perkebunan Sumatera, 4.

${ }^{7} Y$ udianto, Tanaman Lada dalam Perspektif Autekologi, 127.

${ }^{8}$ Karsiwan, Pembangunan Irigasi Way Tebu Sebagai Kebijakan Etis Pemerintah Kolonial Belanda di Pringsewu Tahun, 12.

${ }^{9}$ Kasdi,Memahami Sejarah, 10.

${ }^{10}$ Marsden,Sejarah Sumatera, 212.

${ }^{11}$ Broersma,De Lampongsche Districten,173.

${ }^{12}$ Hadikusuma, Adat Istiadat Daerah Lampung, 122.

${ }^{13}$ Burger, Sejarah Ekonomis Sosiologis Indonesia, 49.

${ }^{14}$ Broersma, De Lampongsche Districten, 168 . 
Tsaqufah \& Tarikh: Jurnal Sejarah dan Kebudayaan

Vol. 5 No. I Januari-Juni 2020

${ }^{15} \mathrm{Ibrahim}$, The Ship of Sulaiman, 177.

${ }^{16}$ Nurhakim, 1989: 267).

${ }^{17}$ Hoedt, Indische Bergcultuurondernemingen Voornamelijk in Zuid Sumatra, 78 .
${ }^{18}$ Vierhout, Het Arbeidsvraagstuk in Verband met de Noodzakelijke

Ontwikkeling der Buitengewesten,82. 